\title{
Copper sulfate and sodium selenite lipid-microencapsulation modifies ruminal microbial fermentation in a dual-flow continuous-culture system
}

\author{
J. A. Arce-Cordero, ${ }^{1}$ H. F. Monteiro, ${ }^{1}$ A. L. Lelis, ${ }^{1}$ L. R. Lima, ${ }^{2}$ R. Restelatto, ${ }^{3}$ V. L. N. Brandao, ${ }^{1}$ H. Leclerc, ${ }^{4}$ \\ D. Vyas, ${ }^{1}$ and A. P. Faciola ${ }^{1 *}$ \\ ${ }^{1}$ Department of Animal Sciences, University of Florida, Gainesville 32611 \\ ${ }^{2}$ Department of Animal Sciences, Federal University of Mato Grosso, Cuiaba, MT, 78060-900, Brazil \\ ${ }^{3}$ Department of Animal Sciences, Federal University of Parana, Curitiba, PR, 80060-000, Brazil \\ ${ }^{4}$ JEFO Nutrition Inc., St. Hyacinthe, QC J2R 2E7, Canada
}

\begin{abstract}
Undesirable interactions between trace mineral elements and ruminal contents may occur during digestion when mineral salts are supplemented. Antimicrobial effects of copper sulfate $\left(\mathrm{CuSO}_{4}\right)$ may affect ruminal digestibility of nutrients when fed as a source of copper $(\mathrm{Cu})$, while sodium selenite $\left(\mathrm{Na}_{2} \mathrm{SeO}_{3}\right)$ may be reduced in the rumen to less available forms of selenium (Se). Our objective was to evaluate if protection of $\mathrm{CuSO}_{4}$ and $\mathrm{Na}_{2} \mathrm{SeO}_{3}$ by lipid-microencapsulation would induce changes on ruminal microbial fermentation. We used 8 fermentors in a dual-flow continuous-culture system in a $4 \times 4$ duplicated Latin square with a $2 \times 2$ factorial arrangement of treatments. Factors were $\mathrm{CuSO}_{4}$ protection (unprotected and protected by lipid-microencapsulation) and $\mathrm{Na}_{2} \mathrm{SeO}_{3}$ protection (unprotected and protected by lipid-microencapsulation). Treatments consisted of supplementation with $15 \mathrm{mg} / \mathrm{kg}$ of $\mathrm{Cu}$ and $0.3 \mathrm{mg} / \mathrm{kg}$ of Se from either unprotected or protected (lipid-microencapsulated) sources, as follows: (1) Control (unprotected $\mathrm{CuSO}_{4}+$ unprotected $\mathrm{Na}_{2} \mathrm{SeO}_{3}$ ); (2) $\mathrm{Cu}-\mathrm{P}$ (protected $\mathrm{CuSO}_{4}+$ unprotected $\mathrm{Na}_{2} \mathrm{SeO}_{3}$ ); (3) Se-P (unprotected $\mathrm{CuSO}_{4}+$ protected $\mathrm{Na}_{2} \mathrm{SeO}_{3}$ ); (4) $(\mathrm{Cu}+\mathrm{Se})-\mathrm{P}$ (protected $\mathrm{CuSO}_{4}+$ protected $\mathrm{Na}_{2} \mathrm{SeO}_{3}$ ). All diets had the same nutrient composition and fermentors were fed $106 \mathrm{~g}$ of dry matter/d. Each experimental period was $10 \mathrm{~d}(7 \mathrm{~d}$ of adaptation and $3 \mathrm{~d}$ for sample collections). Daily pooled samples of effluents were analyzed for $\mathrm{pH}, \mathrm{NH}_{3}-\mathrm{N}$, nutrient digestibility, and flows $\left(\mathrm{g} / \mathrm{d}\right.$ ) of total $\mathrm{N}, \mathrm{NH}_{3}-\mathrm{N}$, nonammonia $\mathrm{N}$ (NAN), bacterial N, dietary N, and bacterial efficiency. Kinetics of volatile fatty acids was analyzed in samples collected daily at $0,1,2,4,6$, and $8 \mathrm{~h}$ after feeding. Main effects of $\mathrm{Cu}$ protection, Se protection, and their interaction
\end{abstract}

Received November 14, 2019.

Accepted March 31, 2020.

*Corresponding author: afaciola@ufl.edu were tested for all response variables. Kinetics data were analyzed as repeated measures. Protection of $\mathrm{Cu}$ decreased acetate molar proportion, increased butyrate proportion, and tended to decrease acetate:propionate ratio in samples of kinetics, but did not modify nutrient digestibility. Protection of Se tended to decrease $\mathrm{NH}_{3}-\mathrm{N}$ concentration, $\mathrm{NH}_{3}-\mathrm{N}$ flow, and $\mathrm{CP}$ digestibility; and to increase flows of nonammonia $\mathrm{N}$ and dietary $\mathrm{N}$. Our results indicate that protection of $\mathrm{CuSO}_{4}$ may increase butyrate concentration at expenses of acetate, while protection of $\mathrm{Na}_{2} \mathrm{SeO}_{3}$ tended to reduce ruminal degradation of N. Further research is needed to determine the effects of lipid-microencapsulation on intestinal absorption, tissue distribution of $\mathrm{Cu}$ and $\mathrm{Se}$, and animal performance.

Key words: in vitro, ruminal digestibility, trace mineral

\section{INTRODUCTION}

Copper and Se play important roles in animal metabolism and it is a common practice to supplement these minerals in ruminants' diets to prevent deficiency (Suttle, 2010). Typically, trace minerals are supplemented as salts; however, in some cases the feeding of conventional mineral salts affects ruminal fermentation (Genther and Hansen, 2015; Faulkner and Weiss, 2017). Also, chemical form of trace mineral elements can be modified in the rumen, which may affect subsequent absorption in the intestine (Suttle, 1975; Suttle, 1991, Galbraith et al., 2016).

Antimicrobial properties of $\mathrm{Cu}$ have been shown to affect in vitro fiber digestibility by ruminal microbes when $\mathrm{Cu}$ concentration of the medium was $2.5 \mathrm{mg} / \mathrm{kg}$ in a batch culture (Hubbert et al., 1958). Additionally, research has shown negative effects of oral supplementation of $\mathrm{Cu}$ salts on nutrient digestibility in ruminants when supplemented at levels between 5 and $25 \mathrm{mg} / \mathrm{kg}$ of $\mathrm{Cu}$ in the diet (Genther and Hansen, 2015; Faulkner and Weiss, 2017; Caldera et al., 2019), allowing for con- 
centrations of soluble $\mathrm{Cu}$ in ruminal fluid ranging from approximately 0.2 to $0.6 \mathrm{mg} / \mathrm{kg}$ (Caldera et al., 2019). Inorganic forms of Se may undergo chemical reduction in the rumen by the action of ruminal microorganisms (Eun et al., 2013), and hence be partially converted to forms of Se with low molecular weight that have not been chemically identified, but are less available to the animal (Weiss, 2005; Suttle, 2010). Moreover, although positive effects of organic forms of Se on ruminal fermentation have been recently reported (Wei et al., 2019), the effects of inorganic Se on ruminal fermentation are not clear (Serra et al., 1994; Kim et al., 1997; Eun et al., 2013). Therefore, there is a critical need to better understand factors that affect ruminal metabolism of $\mathrm{Cu}$ and $\mathrm{Se}$ and their effects on ruminal fermentation.

In the past few decades, trace-mineral nutrition research in ruminants has been primarily focused on the evaluation of alternative mineral sources with a low ruminal solubility that can potentially minimize undesirable interactions between the mineral element and the ruminal contents, while allowing for greater intestinal absorption and improved mineral status of the animal (Spears, 2003; Goff, 2018). However, to the best of our knowledge, no previous research has evaluated protection of trace mineral elements by lipidmicroencapsulation as a strategy to limit their interactions with ruminal contents.

Our objective was to evaluate if protection of copper sulfate $\left(\mathrm{CuSO}_{4}\right)$ and sodium selenite $\left(\mathrm{Na}_{2} \mathrm{SeO}_{3}\right)$ by lipid-microencapsulation would alter ruminal microbial fermentation in a dual-flow continuous-culture system. We hypothesized that the effects of protection would be different for each mineral salt, allowing for improved ruminal fermentation with protected $\mathrm{CuSO}_{4}$, and no effect on ruminal fermentation for protected $\mathrm{Na}_{2} \mathrm{SO}_{3}$ in comparison to the unprotected salts. Due to the negative effects of $\mathrm{CuSO}_{4}$ on ruminal fermentation, we decided to evaluate the interaction between protection effects of both minerals to determine if a response to protection of $\mathrm{Na}_{2} \mathrm{SeO}_{3}$ is observed under more favorable conditions when $\mathrm{CuSO}_{4}$ is protected.

\section{MATERIALS AND METHODS}

\section{Experimental Design and Diets}

All of the procedures for animal care and handling for this experiment were approved by the University of Florida Institutional Animal Use and Care Committee. Eight fermentors in a dual-flow continuous-culture system, with an average volumetric capacity of $1.82 \mathrm{~L}$ each, were used for this experiment in a duplicated 4 $\times 4$ Latin square design with a $2 \times 2$ factorial arrange- ment of treatments. Factors were protection of $\mathrm{CuSO}_{4}$ (unprotected or protected by lipid-microencapsulation) and protection of $\mathrm{Na}_{2} \mathrm{SeO}_{3}$ (unprotected or protected by lipid-microencapsulation). As a result, the following 4 treatments were evaluated: (1) unprotected $\mathrm{CuSO}_{4}+$ unprotected $\mathrm{Na}_{2} \mathrm{SeO}_{3}$ (control); (2) protected $\mathrm{CuSO}_{4}+$ unprotected $\mathrm{Na}_{2} \mathrm{SeO}_{3}(\mathbf{C u}-\mathbf{P})$; (3) unprotected $\mathrm{CuSO}_{4}$ + protected $\mathrm{Na}_{2} \mathrm{SeO}_{3}(\mathbf{S e}-\mathbf{P})$; and (4) protected $\mathrm{CuSO}_{4}$ + protected $\mathrm{Na}_{2} \mathrm{SeO}_{3}[(\mathbf{C u}+\mathbf{S e})-\mathbf{P}]$. Regardless of experimental treatment, all fermentors were provided with $15 \mathrm{mg}$ of supplemental $\mathrm{Cu}$ and $0.3 \mathrm{mg}$ of supplemental Se per kg of diet DM (Table 1). Depending on experimental treatment, $\mathrm{Cu}$ was supplemented as either 6.36 $\mathrm{mg} / \mathrm{d}$ of unprotected $\mathrm{CuSO}_{4}(25 \% \mathrm{Cu})$ or $15.9 \mathrm{mg} / \mathrm{d}$ of protected $\mathrm{CuSO}_{4}(10 \% \mathrm{Cu})$, and Se was supplemented as either $0.074 \mathrm{mg} / \mathrm{d}$ of unprotected $\mathrm{Na}_{2} \mathrm{SeO}_{3}(44 \% \mathrm{Se})$ or $3.18 \mathrm{mg} / \mathrm{d}$ of $\mathrm{Na}_{2} \mathrm{SeO}_{3}$ (1\% Se).

The lipid matrix of protected sources corresponds to a coating of vegetable-origin triglycerides. We achieved a concentration of $10 \% \mathrm{Cu}$ in protected $\mathrm{CuSO}_{4}$ by incorporating $40 \%$ of unprotected $\mathrm{CuSO}_{4}(25 \% \mathrm{Cu})$ into the matrix, and we obtained $1 \%$ of Se in protected $\mathrm{Na}_{2} \mathrm{SeO}_{3}$ by inclusion of $2.3 \%$ of unprotected $\mathrm{Na}_{2} \mathrm{SeO}_{3}$ (44\% Se).

All experimental diets were formulated to the same nutrient concentration (Table 1) to meet or exceed the requirements of a $680 \mathrm{~kg}$ Holstein dairy cow producing $45 \mathrm{~kg}$ of milk per day with $3.5 \%$ fat, $3.0 \%$ protein, and $4.8 \%$ lactose (NRC, 2001). Nutrient composition of all dietary ingredients was determined in samples ground through a 1-mm screen and used as a reference for formulation of experimental diets. Each experimental diet consisted of a basal diet (same for all treatments) plus the corresponding supplemental sources of $\mathrm{Cu}$ and $\mathrm{Se}$ according to treatments.

Major feed ingredients of the basal diet (33\% corn silage, $19 \%$ bermudagrass hay, $25.5 \%$ corn grain, and $20 \%$ soybean meal) were ground through a $2-\mathrm{mm}$ screen in a Wiley mill (model 2; Arthur H. Thomas Co., Philadelphia, PA). Before grinding, corn silage was dried for $72 \mathrm{~h}$ at $60^{\circ} \mathrm{C}$ in a forced-air oven (Heratherm, Thermo Scientific, Waltham, MA), until \%DM was approximately $90 \%$, allowing for proper grinding and storage. Additionally, $\mathrm{CuSO}_{4}$ and $\mathrm{Na}_{2} \mathrm{SeO}_{3}$ (both unprotected and protected) were stored at $4^{\circ} \mathrm{C}$ to keep the integrity of the lipid coat of the protected sources.

\section{Dual-Flow Continuous-Culture System Operation}

A dual-flow continuous-culture system as described by Hoover et al. (1976) was used for this experiment. Briefly, this system maintains a constant outflow of both liquid and solid digesta effluents by individually regulating their passage rates, which allows for suc- 
Table 1. Ingredient and chemical composition of experimental diets

\begin{tabular}{|c|c|c|c|c|}
\hline \multirow[b]{2}{*}{ Item } & \multicolumn{4}{|c|}{ Treatment $^{1}$} \\
\hline & Control & $\mathrm{Cu}-\mathrm{P}$ & Se-P & $(\mathrm{Cu}+\mathrm{Se})-\mathrm{P}$ \\
\hline \multicolumn{5}{|l|}{ Ingredient composition, ${ }^{2} \%$ of DM } \\
\hline Basal diet ${ }^{3}$ & 99.982 & 99.982 & 99.982 & 99.982 \\
\hline Unprotected $\mathrm{CuSO}_{4}(25 \% \mathrm{Cu})$ & 0.006 & 0 & 0.006 & 0 \\
\hline Protected $\mathrm{CuSO}_{4}(10 \% \mathrm{Cu})$ & 0 & 0.015 & 0 & 0.015 \\
\hline Unprotected $\mathrm{Na}_{2} \mathrm{SeO}_{3}(44 \% \mathrm{Se})$ & 0.00007 & 0.00007 & 0 & 0 \\
\hline Protected $\mathrm{Na}_{2} \mathrm{SeO}_{3}(1 \% \mathrm{Se})$ & 0 & 0 & 0.003 & 0.003 \\
\hline Vegetable-origin triglycerides ${ }^{4}$ & 0.01193 & 0.00293 & 0.009 & 0 \\
\hline \multicolumn{5}{|l|}{$\begin{array}{l}\text { Chemical composition, \% of DM } \\
\text { unless otherwise noted }\end{array}$} \\
\hline $\mathrm{CP}$ & 16.1 & 16.1 & 16.1 & 16.1 \\
\hline Ether extract & 2.8 & 2.8 & 2.8 & 2.8 \\
\hline NDF & 31.65 & 31.65 & 31.65 & 31.65 \\
\hline Starch & 29.48 & 29.48 & 29.48 & 29.48 \\
\hline $\mathrm{NE}_{\mathrm{L}}, \mathrm{Mcal} / \mathrm{kg}$ & 1.60 & 1.60 & 1.60 & 1.60 \\
\hline $\mathrm{S}$ & 0.21 & 0.21 & 0.21 & 0.21 \\
\hline $\mathrm{Ca}$ & 0.68 & 0.68 & 0.68 & 0.68 \\
\hline $\mathrm{P}$ & 0.41 & 0.41 & 0.41 & 0.41 \\
\hline $\mathrm{Cu}, \mathrm{mg} / \mathrm{kg}$ & 18.36 & 18.36 & 18.36 & 18.36 \\
\hline $\mathrm{Se}, \mathrm{mg} / \mathrm{kg}$ & 0.42 & 0.42 & 0.42 & 0.42 \\
\hline $\mathrm{Cu}$ from $\mathrm{CuSO}_{4},{ }^{5} \mathrm{mg} / \mathrm{kg}$ & 15.0 & 15.0 & 15.0 & 15.0 \\
\hline Se from $\mathrm{Na}_{2} \mathrm{SeO}_{3},{ }^{6} \mathrm{mg} / \mathrm{kg}$ & 0.3 & 0.3 & 0.3 & 0.3 \\
\hline $\begin{array}{l}{ }^{1} \text { Control (unprotected } \mathrm{CuSO}_{4}+\mathrm{u} \\
\text { (unprotected } \mathrm{CuSO}_{4}+\text { protected } \\
{ }^{2} \text { Level of inclusion of } \mathrm{CuSO}_{4} \text { and } \\
{ }^{3} \text { Basal diet composition }(\mathrm{DM} \text { basi } \\
\text { meal, } 1 \% \mathrm{CaCO}_{3}, 0.5 \% \mathrm{Ca}_{3}\left(\mathrm{PO}_{4}\right)_{2} \\
{ }^{4} \mathrm{Same} \text { as used for lipid-microenca } \\
{ }^{5} \text { Fraction of } \mathrm{Cu} \text { provided exclusive } \\
{ }^{6} \text { Fraction of Se provided exclusive }\end{array}$ & $\begin{array}{l}3 \text { ); } \mathrm{Cu}-\mathrm{P}(\mathrm{p} \\
\text { )-P (protec } \\
\text { sed as a pe } \\
19 \% \text { bern } \\
\text { te } \mathrm{NaCl}, 0 \text {. } \\
\text { ted minera }\end{array}$ & $\begin{array}{l}\text { cted } \mathrm{CuSO} \\
\mathrm{CuSO}_{4}+\mathrm{p} \\
\mathrm{t} \text { of basal } \\
\text { grass hay, } \\
\mathrm{MgSO}_{4}, 0.0\end{array}$ & $\begin{array}{l}\text { unprotec } \\
\text { cted } \mathrm{Na}_{2} \\
\text { \% corn } \\
\mathrm{ZnSO}_{4} .\end{array}$ & $\begin{array}{l}\left.\mathrm{Na}_{2} \mathrm{SeO}_{3}\right) ; \mathrm{Se}-\mathrm{F} \\
3) . \\
n, 20 \% \text { soybeal }\end{array}$ \\
\hline
\end{tabular}

cessful ruminal fermentation simulation (Brandao and Faciola, 2019; Brandao et al., 2020).

In this experiment, a total of $40 \mathrm{~d}$ of fermentation were distributed among 4 fermentation periods of $10 \mathrm{~d}$ each. Fermentors were inoculated once at the beginning of each fermentation period (d 1) with fresh ruminal contents that were maintained in continuous culture for $10 \mathrm{~d}$. Ruminal contents were collected from 2 ruminally cannulated multiparous Holstein cows in mid lactation (84 DIM on average). From d -20 to d 40 of the experiment, both cannulated cows were fed twice a day a TMR with the following composition (on a DM basis): $38 \%$ corn silage, $19 \%$ ground corn, $13 \%$ soybean meal, $11 \%$ cotton seed, $9 \%$ citrus pulp, $8.5 \%$ mineral premix, and $1.5 \%$ palmitic acid supplement. For each collection, ruminal contents of each cow were manually strained through 2 layers of cheesecloth approximately $1 \mathrm{~h}$ after morning feeding until $8 \mathrm{~L}$ of contents were obtained from each cow, collected in pre-warmed thermos jars, immediately transported to the laboratory, and poured into the pre-warmed fermentors under continuous flush of $\mathrm{N}_{2}$ gas. Each fermentor was filled with a 50:50 mix (vol/vol) of ruminal contents from both cows.
Experimental diets were provided to each fermentor in $53 \mathrm{~g}$ of DM portions at 0800 and 1800 at a constant rate of $106 \mathrm{~g}$ of $\mathrm{DM} / \mathrm{d}$. Additionally, experimental conditions were held constant throughout the entire experimental period with continuous agitation at 100 $\mathrm{rpm}, 39^{\circ} \mathrm{C}$ temperature, infusion of artificial saliva (Weller and Pilgrim, 1974) at $3.05 \mathrm{~mL} / \mathrm{min}, 11 \% / \mathrm{h}$ liquid dilution rate, and $5.5 \% / \mathrm{h}$ solid dilution rate. On d 5 of each period, $0.1733 \mathrm{~g}$ of $\left({ }^{15} \mathrm{NH}_{4}\right)_{2} \mathrm{SO}_{4} 10.2 \%$ atom excess (Sigma Aldrich Co.) was pulse dosed into each fermentor (to create a steady state of ${ }^{15} \mathrm{~N}$ ), and then continuously added as a marker in artificial saliva at a rate of $0.077 \mathrm{~g} / \mathrm{L}$ until the end of the fermentation period. From d 8 to d 10 of fermentation, solid and liquid effluent collection containers were kept in an icecold water bath and maintained below $2^{\circ} \mathrm{C}$ to prevent further microbial fermentation of nutrients outside of the fermentors.

\section{Collection of Data and Samples}

Data and samples were collected during the last 3 $d$ of each experimental period for analyses of nutrient 
digestibility, VFA, ammonia $\mathrm{N}\left(\mathrm{NH}_{3}-\mathrm{N}\right)$, and ${ }^{15} \mathrm{~N}$ for determination of $\mathrm{N}$ metabolism, as described below.

\section{Nutrient Digestibility}

Ruminal digestibility of nutrients was determined from samples collected on d 8, 9, and 10 of each period. Once per day before morning feed-provision time, liquid and solid digesta effluents of the same fermentor (representing $24 \mathrm{~h}$ of fermentation) were weighed, combined, and mixed for $60 \mathrm{~s}$; then a sample of $500 \mathrm{~g}$ of digesta was collected and stored at $-20^{\circ} \mathrm{C}$. Samples of digesta from the same fermentor and period were pooled across the 3 collection days, then a 200-mL composite sample per fermentor per period was freeze-dried, ground with a mortar and pestle, and stored in a plastic container for further analyses to determine ruminal digestibility of DM, OM, CP, and NDF. Samples were analyzed in duplicates.

\section{Daily Average $\mathrm{pH}$ and $\mathrm{NH}_{3}-\mathrm{N}$ Concentration}

Before morning feed provision on d 8, 9, and 10 of each period, $\mathrm{pH}$ was measured and a sample was collected from the mixed digesta effluent (solid and liquid) from each fermentor (same as samples for digestibility analyses). A 10-mL sample of mixed digesta effluent was strained through 4 layers of cheesecloth into a 15 -mL centrifuge tube, acidified with $100 \mu \mathrm{L}$ of $50 \%$ $\mathrm{H}_{2} \mathrm{SO}_{4}$ and stored at $-20^{\circ} \mathrm{C}$ for further analysis of $\mathrm{NH}_{3}-$ N. Daily samples were kept separate, and 3 samples per fermentor per period were analyzed for $\mathrm{NH}_{3}-\mathrm{N}$. Samples were run in duplicates.

\section{Diurnal Variation (Kinetics) of VFA Concentration}

Samples for VFA kinetics analysis were collected from each fermentor on $\mathrm{d} 8,9$, and 10 of each period at $0,1,2,4,6$, and $8 \mathrm{~h}$ after morning feed provision. For each time point, a $10-\mathrm{mL}$ sample of ruminal fluid was strained through 4 layers of cheesecloth and collected into a 15-mL centrifuge tube (cat. no. 14955237, Fisher Scientific, Waltham, MA) with $100 \mu \mathrm{L}$ of $50 \% \mathrm{H}_{2} \mathrm{SO}_{4}$ and stored at $-20^{\circ} \mathrm{C}$. Samples corresponding to the same time point, fermentor, and period, collected over 3 consecutive days, were combined across days for VFA analysis. All samples were run in duplicates.

\section{Percent Atom ${ }^{15} \mathrm{~N}$ Analysis}

A sample of $200 \mathrm{~mL}$ of ${ }^{15} \mathrm{~N}$-enriched artificial saliva was collected each period on d 5 of fermentation for measurement of ${ }^{15} \mathrm{~N}$ concentration. Also, $200 \mathrm{~mL}$ of mixed digesta effluent (solid and liquid) were collected from each fermentor before morning feed provision on d 5 of each period before infusion of ${ }^{15} \mathrm{~N}$-enriched saliva to measure the ${ }^{15} \mathrm{~N}$ background concentration in digesta (background sample). The same composite sample of digesta effluent collected on d 8, 9, and 10 for ruminal digestibility analyses was also used for measurement of ${ }^{15} \mathrm{~N}$ concentration in digesta effluent. Additionally, on d 10 of each period, the whole content of each fermentor was processed for isolation of bacteria according to Krizsan et al. (2010) by blending for $30 \mathrm{~s}$, followed by filtering through 4 layers of cheesecloth with 400 $\mathrm{mL}$ of $0.9 \%$ saline solution. The filtrate was centrifuged (Sorvall RC-5B Refrigerated Superspeed Centrifuge, DuPont Instruments, Newtown, CT) at $1,000 \times g$ for 10 min to precipitate and discard the feed particles; then, the supernatant was centrifuged at 11,250 $\times \mathrm{g}$ for $20 \mathrm{~min}$ to harvest the pellet of bacteria that was subsequently re-suspended in $200 \mathrm{~mL}$ of McDougall's solution, and centrifuged at $16,250 \times g$ for $20 \mathrm{~min}$ for a more efficient recovery of bacteria pellet. Pellet was transferred with distilled water into a plastic container for storage.

Immediately after collection, samples of ${ }^{15} \mathrm{~N}$-enriched saliva, ${ }^{15} \mathrm{~N}$ background, digesta effluent, and bacteria, were stored at $-20^{\circ} \mathrm{C}$ until freeze-dried. Dried samples were ground with a mortar and pestle and subsequently ball-milled at $25 \mathrm{~Hz}$ for 9 min using a Mixer Mill MM400 (Retsch, Newton, PA) for further analysis of ${ }^{15} \mathrm{~N}$.

\section{Laboratory Analyses}

Samples of dietary feed ingredients (corn silage, grass hay, corn grain, and soybean meal) and freeze-dried digesta were analyzed for chemical composition as follows: DM (AOAC, 1990; method 930.15), ash (AOAC, 1990; method 942.05), NDF (Van Soest et al., 1991) adapted for Ankom ${ }^{200}$ Fiber Analyzer (Ankom Technology, Macedon, NY) with heat-stable $\alpha$-amylase and sodium sulfite, and total N (AOAC International, 2000; method 990.03) by rapid combustion with a micro elemental N analyzer (Vario Micro Cube, Elementar, Hanau, Germany). Additionally, feed ingredients used for experimental diets were analyzed for concentration of total starch by enzymatic hydrolysis (Hall, 2015), Se by atomic absorption (AOAC International, 2000; method 996.16), and $\mathrm{Ca}, \mathrm{P}, \mathrm{S}$, and $\mathrm{Cu}$ by inductively coupled plasma mass spectrometry (AOAC International, 2000; method 985.01).

Concentration of VFA (acetate, propionate, butyrate, isobutyrate, isovalerate, valerate, and caproate) was analyzed by gas chromatography (Agilent 7820A GC, Agilent Technologies, Palo Alto, CA) with a flame 
ionization detector and a capillary column (CP-WAX 58 FFAP $25 \mathrm{~m} 0.53 \mathrm{~mm}$, Varian CP7767, Varian Analytical Instruments, Walnut Creek, CA) that was maintained at $110^{\circ} \mathrm{C}$, with injector temperature at $200^{\circ} \mathrm{C}$ and detector at $220^{\circ} \mathrm{C}$. Samples were thawed at room temperature and processed according to Ruiz-Moreno et al. (2015) by centrifuging at $10,000 \times g$ for $15 \mathrm{~min}$, mixing the supernatant with a solution of crotonic acid and metaphosphoric acid to freeze overnight, and then centrifuge again at $10,000 \times g$ for $15 \mathrm{~min}$. The supernatant was mixed with ethyl acetate, vortexed, and allowed to settle to finally transfer the top layer to a chromatography injection vial for analysis.

Analysis of $\mathrm{NH}_{3}-\mathrm{N}$ was performed with the phenolhypochlorite method according to Broderick and Kang (1980). Samples were thawed at room temperature, centrifuged at $10,000 \times g$ for $15 \mathrm{~min}$, and the supernatant used for analysis. Reaction was carried out in a 96-well flat-bottom plate, and absorbance measured in a spectrophotometer at $620 \mathrm{~nm}$ (SpectraMax Plus 384 Microplate Reader, Molecular Devices, San Jose, CA).

For ${ }^{15} \mathrm{~N}$ analysis, between 1 and $4 \mathrm{mg}$ of ball-milled sample (depending on sample type and expected concentration of ${ }^{15} \mathrm{~N}$ ) were weighed in a $8 \times 5 \mathrm{~mm}$ pressed standard-weight tin capsule (Elemental microanalysis, Devon, UK) using a Mettler Toledo Excellence Plus XP Micro Balance (Mettler-Toledo GmbH, Laboratory \& Weighing Technologies, Greifensee, Switzerland). Then, $35 \mu \mathrm{L}$ of $\mathrm{K}_{2} \mathrm{CO}_{3}$ solution $(10 \mathrm{~g} / \mathrm{L})$ was added to each sample and left overnight in a forced-air oven at $40^{\circ} \mathrm{C}$ for complete evaporation of $\mathrm{NH}_{3}-\mathrm{N}$. Finally, \% atom ${ }^{15} \mathrm{~N}$ in samples was determined by isotope ratio mass spectrometry (IsoPrime 100, IsoPrime, Manchester, UK) and expressed as the fractional abundance of isotopic fractions $\left({ }^{15} \mathrm{~N} /{ }^{14} \mathrm{~N}\right)$ multiplied by 100 . Additionally, these samples were analyzed for DM (AOAC, 1990; method 930.15), ash (AOAC, 1990; method 942.05), and concentration of total N (AOAC International, 2000; method 990.03) by rapid combustion with a micro elemental $\mathrm{N}$ analyzer (Vario Micro Cube, Elementar, Hanau, Germany).

\section{Calculations for N Metabolism and Digestibility of Nutrients}

The forms of $\mathrm{N}$ present in digesta effluent represent the transformation of $\mathrm{N}$ by ruminal microorganisms during fermentation. Total $\mathrm{N}$ content in digesta effluent may be partitioned into 3 main fractions: $\mathrm{NH}_{3}-\mathrm{N}$ flow, dietary $\mathrm{N}$ flow (undigested), and bacterial $\mathrm{N}$ flow. The 2 latter fractions combined are also known as NAN.

For this experiment, flows of $\mathrm{NH}_{3}-\mathrm{N}$ and NAN were determined according to Bach and Stern (1999) using the following equations:

$$
\mathrm{NH}_{3}-\mathrm{N} \text { flow }(\mathrm{g} / \mathrm{d})=\mathrm{NH}_{3}-\mathrm{N} \text { concentration }
$$

in effluent $(\mathrm{mg} / \mathrm{dL}) \times(\mathrm{mL}$ of total effluent flow/100),

NAN flow $(\mathrm{g} / \mathrm{d})=\mathrm{g}$ of total $\mathrm{N}$ in effluent $-\mathrm{g}$ of effluent $\mathrm{NH}_{3}-\mathrm{N}$.

Moreover, flow of bacterial $\mathrm{N}$ was determined based on $\%$ atom excess of ${ }^{15} \mathrm{~N}$ in NAN and bacteria, according to Calsamiglia et al. (1996):

$$
\text { Bacterial } \mathrm{N} \text { flow }(\mathrm{g} / \mathrm{d})=
$$

(NAN flow $\times \%$ atom excess of ${ }^{15} \mathrm{~N}$ in NAN effluent)/

$$
\text { (\% atom excess of }{ }^{15} \mathrm{~N} \text { in bacteria pellet); }
$$

where $\%$ atom excess of ${ }^{15} \mathrm{~N}$ in NAN effluent $=\%$ atom ${ }^{15} \mathrm{~N}$ in NAN effluent sample $-\%$ atom ${ }^{15} \mathrm{~N}$ in background.

Additionally, flow of dietary $\mathrm{N}$ and indicators of $\mathrm{N}$ metabolism by microorganisms were also determined according to Bach and Stern (1999) as follows:

$$
\begin{gathered}
\text { Dietary } \mathrm{N} \text { flow }(\mathrm{g} / \mathrm{d})=\mathrm{g} \text { of NAN in effluent } \\
-\mathrm{g} \text { of bacterial } \mathrm{N} \text { in effluent; } \\
\text { Bacterial efficiency }=
\end{gathered}
$$

bacterial $\mathrm{N}$ flow (g)/OM truly digested (kg);

$$
\text { Efficiency of } \mathrm{N} \text { use }=
$$

$(\mathrm{g}$ of bacterial N/g of available $\mathrm{N}) \times 100$.

Ruminal digestibility of DM, OM, CP, and NDF were calculated according to Soder et al. (2013) by accounting for the proportion of undigested nutrients present in the digesta effluent, and after correcting for the contributions of artificial saliva and bacteria, as shown:

$$
\% \text { Nutrient digestibility (DM basis) }=
$$

$100 \times$ [g of nutrient intake - ( $\mathrm{g}$ of nutrient in effluent

$-\mathrm{g}$ of nutrient in saliva $-\mathrm{g}$ of nutrient in bacteria)]/

$$
\mathrm{g} \text { of nutrient intake. }
$$

\section{Statistical Analysis}

We performed ANOVA with the MIXED procedure of SAS 9.4 (SAS Institute Inc., Cary, NC). Data were analyzed as a $4 \times 4$ Latin square design with a $2 \times 2$ factorial arrangement of treatments. The fixed effects of protection by lipid-microencapsulation of $\mathrm{CuSO}_{4}$ $(\mathrm{Cu}), \mathrm{Na}_{2} \mathrm{SeO}_{3}(\mathrm{Se})$, and their interaction $(\mathrm{Cu} \times \mathrm{Se})$ 
were tested for all of the response variables. Random effects of square, period, and fermentor within square were also included in the models. Additionally, for evaluation of diurnal variation (kinetics) of VFA molar proportions, the effect of time (expressed as $\mathrm{h}$ after morning feeding) was included as a fixed effect in the model, and data were analyzed as repeated measures. The following covariance matrix structures were chosen based on lowest Akaike information criterion: first-order auto $=$ regressive structure (acetate, propionate, butyrate, and acetate:propionate ratio), Toeplitz structure $[\mathrm{pH}$, isobutyrate, and branched-chain VFA (BCVFA)]; and compound symmetry structure (isovalerate, valerate, and caproate). Threshold for significance was defined at $P \leq 0.05$, while $0.05<P<0.10$ was considered as a trend. Multiple comparisons between treatments were evaluated with Tukey's test.

\section{RESULTS AND DISCUSSION}

\section{VFA Concentration}

Diurnal variation (kinetics) of molar proportion of individual VFA is presented in Figures 1 through 6 as molar proportions of total VFA. Protection of $\mathrm{CuSO}_{4}$ lowered molar proportion of acetate $(P=0.02$, Figure 1 ), did not affect molar proportion of propionate (Figure 2), and increased increased molar proportion of butyrate $(P=0.04$, Figure 3$)$. Additionally, protection of
$\mathrm{CuSO}_{4}$ tended to reduce $(P=0.06)$ acetate:propionate ratio (Figure 4). Based on previous research, these results suggest that protection of $\mathrm{CuSO}_{4}$ by micro-encapsulation may favor a VFA-synthesis profile allowing for a greater energy supply to the ruminal epithelium (Kristensen and Harmon, 2004).

Effects of supplementing sulfate trace mineral sources on ruminal fermentation have been previously evaluated. Pino and Heinrichs (2016) reported greater total VFA and butyrate molar proportion in Holstein heifers fed sulfate trace minerals compared with organic proteinates. Guimaraes et al. (2019) observed greater total VFA concentration and lower molar proportion of butyrate in Angus steers fed low-quality hay with a protein supplement. Although the effects of sulfate minerals on VFA synthesis are still not clear, it appears that lower concentrations of one or more VFAs are normally observed. Moreover, the variation observed across experiments may be a consequence of an existing interaction between mineral source and type of diet (Faulkner and Weiss, 2017). One limitation of most available data is that many experiments compared sulfate trace mineral sources to organic sources; therefore, in addition to $\mathrm{Cu}, \mathrm{Zn}$ and $\mathrm{Mn}$ were included in the mineral supplement and consequently the findings correspond to the combined effect of the 3 minerals on ruminal fermentation.

Based on results from the present study, we could speculate that butyrate-producing bacteria may be



Figure 1. Effect of protection of $\mathrm{CuSO}_{4}$ and $\mathrm{Na}_{2} \mathrm{SeO}_{3}$ on diurnal variation of acetate molar proportion in a dual-flow continuous-culture system. Treatments: control (unprotected $\mathrm{CuSO}_{4}+$ unprotected $\mathrm{Na}_{2} \mathrm{SeO}_{3}$ ); $\mathrm{Cu}-\mathrm{P}$ (protected $\mathrm{CuSO}_{4}+$ unprotected $\mathrm{Na}_{2} \mathrm{SeO}$ ); $\mathrm{Se}-\mathrm{P}($ unprotected $\mathrm{CuSO}_{4}+$ protected $\left.\mathrm{Na}_{2} \mathrm{SeO}_{3}\right) ;(\mathrm{Cu}+\mathrm{Se})-\mathrm{P}$ (protected $\mathrm{CuSO}_{4}+$ protected $\left.\mathrm{Na}_{2} \mathrm{SeO}_{3}\right)$. Effects: Cu (main effect of CuSO $\mathrm{Cu}_{4}$ protection); Se (main effect of $\mathrm{Na}_{2} \mathrm{SeO}_{3}$ protection); $\mathrm{Cu} \times \mathrm{Se}$ (interaction between $\mathrm{CuSO}_{4}$ protection and $\mathrm{Na}_{2} \mathrm{SeO}_{3}$ protection). Error bars represent the $\mathrm{SEM}$. 


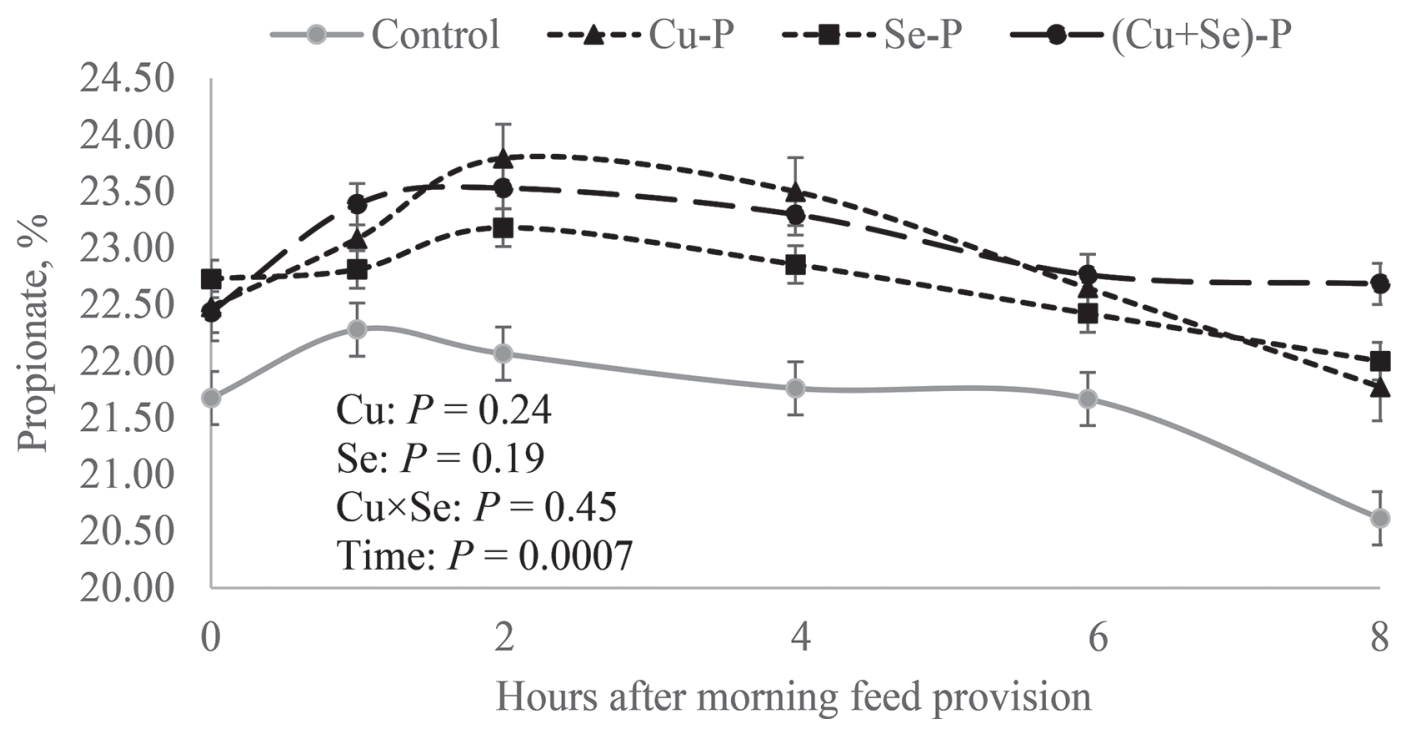

Figure 2. Effect of protection of $\mathrm{CuSO}_{4}$ and $\mathrm{Na}_{2} \mathrm{SeO}_{3}$ on diurnal variation of propionate molar proportion in a dual-flow continuous-culture system. Treatments: control (unprotected $\mathrm{CuSO}_{4}+$ unprotected $\mathrm{Na}_{2} \mathrm{SeO}_{3}$ ); $\mathrm{Cu}-\mathrm{P}$ (protected $\mathrm{CuSO}_{4}+$ unprotected $\mathrm{Na}_{2} \mathrm{SeO}$ ); $\mathrm{Se}-\mathrm{P}($ unprotected $\mathrm{CuSO}_{4}+$ protected $\left.\mathrm{Na}_{2} \mathrm{SeO}_{3}\right) ;(\mathrm{Cu}+\mathrm{Se})-\mathrm{P}$ (protected $\mathrm{CuSO}_{4}+$ protected $\mathrm{Na}_{2} \mathrm{SeO}_{3}$ ). Effects: $\mathrm{Cu}$ (main effect of CuSO $\mathrm{C}_{4}$ protection); Se (main effect of $\mathrm{Na}_{2} \mathrm{SeO}_{3}$ protection); $\mathrm{Cu} \times \mathrm{Se}$ (interaction between $\mathrm{CuSO}_{4}$ protection and $\mathrm{Na}_{2} \mathrm{SeO}_{3}$ protection). Error bars represent the SEM.

more sensitive to $\mathrm{CuSO}_{4}$ compared with propionate- and acetate-producing bacteria, and therefore protection by lipid-microencapsulation enhances molar proportion of butyrate. Also, the increase in butyrate molar proportion may have occurred at expense of acetate, considering that butyrate can be synthesized from acetate by ruminal bacteria such as Butyrivibrio (Hackmann and Firkins, 2015). Moreover, this genus also plays a role in fatty acid biohydrogenation; therefore, greater butyrate concentration associated with protection of $\mathrm{CuSO}_{4}$ in our experiment may have favored a greater extent of lipid biohydrogenation, which, although not evaluated in our experiment, fits with previous reports of reduced lipid biohydrogenation in Angus steers supplemented with $\mathrm{CuSO}_{4}$ (Engle and Spears, 2000; Engle et al., 2000).

No effects were observed with protection of $\mathrm{Na}_{2} \mathrm{SeO}_{3}$ on diurnal variation of molar proportions of acetate $(P$ $=0.23 ;$ Figure 1$)$, propionate $(P=0.19 ;$ Figure 2$)$, and butyrate $(P=0.45$; Figure 3$)$. However, the interaction between the protection effects of $\mathrm{CuSO}_{4}$ and $\mathrm{Na}_{2} \mathrm{SeO}_{3}$ $(\mathrm{Cu} \times \mathrm{Se})$ was significant for molar proportions of isovalerate $(P=0.01$, Figure 5$)$ and BCVFA $(P=0.02$, Figure 6$)$. The molar proportions of isovalerate and BCVFA were greater for $\mathrm{Cu}-\mathrm{P}$ treatment when compared with control, $(\mathrm{Cu}+\mathrm{Se})-\mathrm{P}$, and Se-P; indicating a greater degradation of branched-chain AA by ruminal microorganisms only when protected $\mathrm{CuSO}_{4}$ was fed with unprotected $\mathrm{Na}_{2} \mathrm{SeO}_{3}$, suggesting a possible role of Se on ruminal N metabolism. Similar findings were reported by Hidiroglou and Lessard (1976), who observed greater proportion of isovalerate in ruminal fluid of sheep fed a purified diet supplemented with $1 \mathrm{mg}$ of unprotected $\mathrm{Na}_{2} \mathrm{SeO}_{3}$ per week.

Other studies have reported different effects of inorganic Se supplementation on VFA. Kim et al. (1997) observed a greater molar proportion of butyrate at the expense of acetate when supplemented unprotected $\mathrm{Na}_{2} \mathrm{SeO}_{3}$ at a concentration of $2 \mathrm{mg} / \mathrm{kg}$ Se in a batch culture; conversely, elemental Se did not have any effect on fermentation. Shi et al. (2011) observed a greater molar proportion of propionate in ruminal fluid of sheep fed nano Se at $0.3,3$, and $6 \mathrm{mg} / \mathrm{kg}$ compared with the unsupplemented control. Different fermentative responses to Se supplementation may be due to variation in concentration of Se in basal diets across experiments, and also due to different type and composition of those diets, type of animals, and length of fermentations or incubations evaluated.

Shifts in ruminal fermentation after supplementing inorganic Se may be indicative of either a requirement of Se by ruminal microorganisms or an alteration of fermentation by the chemical reduction of Se compounds (selenate to selenite to elemental Se). Nevertheless, changes in VFA and ruminal fermentation have also been reported in dairy cows (Wei et al., 2019) fed 0.3 and $0.5 \mathrm{mg} / \mathrm{kg}$ of organic Se (hydroxy-analog of Se-methionine), which may be a response of ruminal microorganisms to the AA analog rather than an effect of Se. 


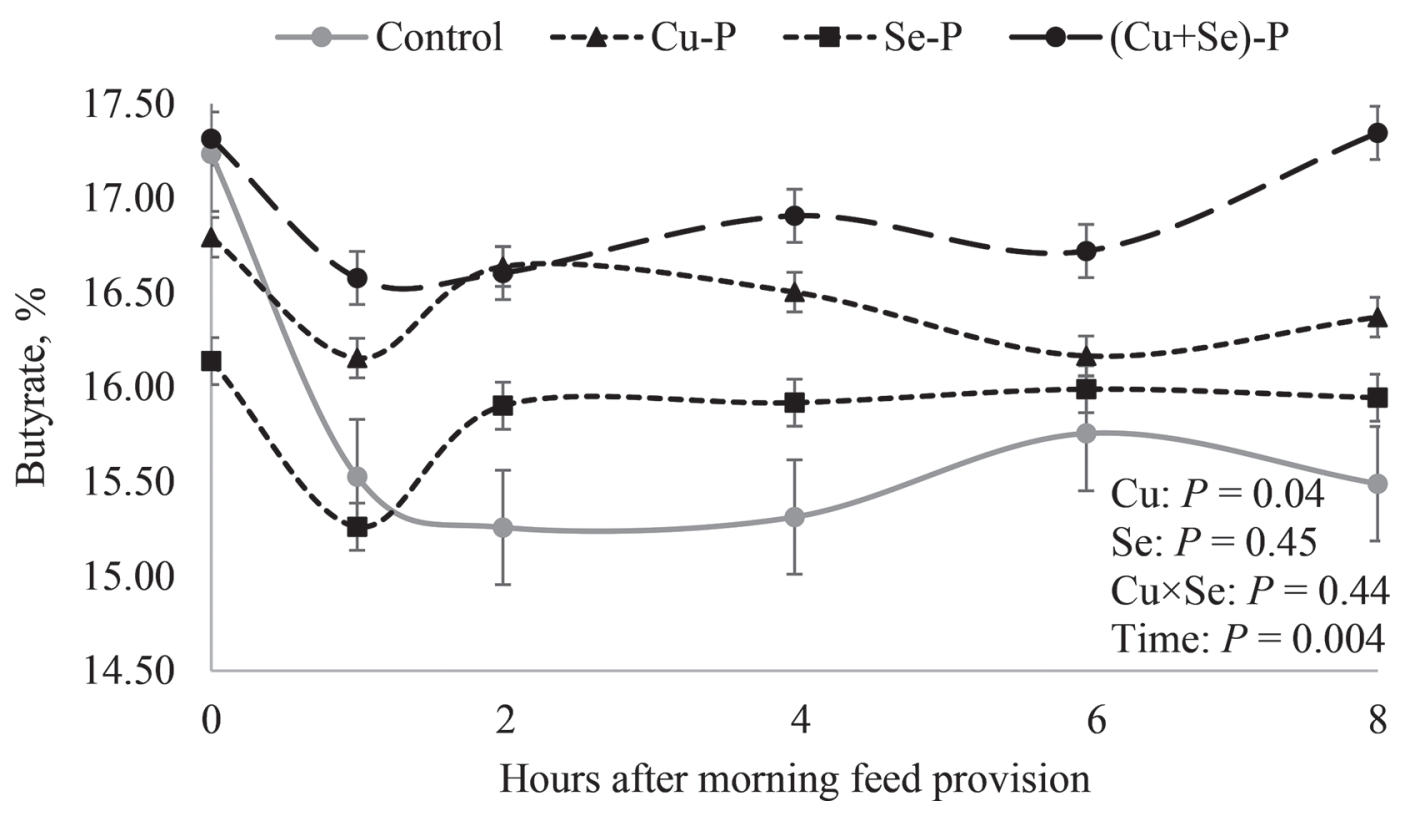

Figure 3. Effect of protection of $\mathrm{CuSO}_{4}$ and $\mathrm{Na}_{2} \mathrm{SeO}_{3}$ on diurnal variation of butyrate molar proportion in a dual-flow continuous-culture system. Treatments: control (unprotected $\mathrm{CuSO}_{4}+$ unprotected $\mathrm{Na}_{2} \mathrm{SeO}_{3}$ ); $\mathrm{Cu}-\mathrm{P}$ (protected $\mathrm{CuSO}_{4}+$ unprotected $\mathrm{Na}_{2} \mathrm{SeO}$ ); $\mathrm{Se}-\mathrm{P}($ unprotected $\mathrm{CuSO}_{4}+$ protected $\left.\mathrm{Na}_{2} \mathrm{SeO}_{3}\right) ;(\mathrm{Cu}+\mathrm{Se})-\mathrm{P}$ (protected $\mathrm{CuSO}_{4}+$ protected $\mathrm{Na}_{2} \mathrm{SeO}_{3}$ ). Effects: $\mathrm{Cu}$ (main effect of CuSO $\mathrm{C}_{4}$ protection); Se (main effect of $\mathrm{Na}_{2} \mathrm{SeO}_{3}$ protection); $\mathrm{Cu} \times \mathrm{Se}$ (interaction between $\mathrm{CuSO}_{4}$ protection and $\mathrm{Na}_{2} \mathrm{SeO}_{3}$ protection). Error bars represent the SEM.

\section{Flows of $\mathbf{N}$ and $\mathbf{N}$ Metabolism}

The effects of lipid-microencapsulation protection of $\mathrm{CuSO}_{4}$ and $\mathrm{Na}_{2} \mathrm{SeO}_{3}$ on concentration of $\mathrm{NH}_{3}-\mathrm{N}$ were analyzed in samples of digesta effluent and used for estimation of $\mathrm{N}$ flows (Table 2). Protection of $\mathrm{CuSO}_{4}$ did not have an effect on $\mathrm{N}$ metabolism. However, a trend $(P=0.09)$ was observed for protection of $\mathrm{Na}_{2} \mathrm{SeO}_{3}$ to decrease average daily concentration of $\mathrm{NH}_{3}-\mathrm{N}$ in the effluent, indicating lesser $\mathrm{N}$ degradation.

The daily outflows $(\mathrm{g} / \mathrm{d})$ of different fractions of $\mathrm{N}$ were also determined, and represent what remains from each fraction after microbial fermentation (Table 2). In agreement with the results observed for $\mathrm{NH}_{3}-\mathrm{N}$ concentration in effluent, protection of $\mathrm{Na}_{2} \mathrm{SeO}_{3}$ also showed a trend toward reduced outflow of $\mathrm{NH}_{3}-\mathrm{N}(P=0.07)$ and increased flows of both NAN $(P=0.06)$ and dietary $\mathrm{N}(P=0.06)$; indicating that protection of $\mathrm{Na}_{2} \mathrm{SeO}_{3}$ tended to reduce degradability of dietary $\mathrm{N}$, but did not affect flow of bacterial N. These results match well with the observed effects of $\mathrm{Na}_{2} \mathrm{SeO}_{3}$ protection on BCVFA concentrations, suggesting that unprotected $\mathrm{Na}_{2} \mathrm{SeO}_{3}$ may increase ruminal degradation of $\mathrm{N}$, and therefore molar proportions of isovalerate and BCVFA.

In vitro evaluations in batch cultures by Kim et al. (1997) did not show any effects of supplemental Se on bacterial yield after 24 and $48 \mathrm{~h}$ of fermentation. Serra et al. (1994) did not find any effect of Se on ruminal bacteria yield in sheep supplemented with either selenite or selenate; however, a negative correlation between Se concentration in ruminal fluid and yield of ruminal bacteria was observed. Between-species differences have been reported on the capacity of bacteria to grow in medium with increasing concentrations of Se, and low or absent concentrations of sulfur (Shamberger, 1983), indicating differences in tolerance to Se and ability to replace sulfur by Se during AA synthesis process. However, this has not yet been well established for ruminal bacteria.

Shi et al. (2011) found a quadratic decrease in ruminal $\mathrm{NH}_{3}-\mathrm{N}$ concentration of sheep with increasing level of inclusion of supplemental nano Se at 0, 0.3, 3.0 and $6.0 \mathrm{mg} / \mathrm{kg}$. Nano selenium refers to nanometer particulates of elemental Se with oxidation state 0. Based on the improvement in fermentation (greater total VFA and propionate concentrations) and digestibility in response to Se supplementation, the authors suggested that lower $\mathrm{NH}_{3}-\mathrm{N}$ concentration might have been due to increased $\mathrm{N}$ uptake for microbial protein synthesis. Wei et al. (2019) also observed a decrease in ruminal $\mathrm{NH}_{3}-\mathrm{N}$ along with improved fermentation in dairy cows fed hydroxy-analog of Se-methionine at 0, 0.3, and 0.5 $\mathrm{mg} / \mathrm{kg}$ of Se, suggesting greater $\mathrm{NH}_{3}-\mathrm{N}$ utilization due to enhanced microbial growth.

Our results showed a reduction in $\mathrm{NH}_{3}-\mathrm{N}$ concentration as a consequence of protecting $\mathrm{Na}_{2} \mathrm{SeO}_{3}$ by lipid-microencapsulation. Two possible reasons for this outcome were (1) reduced synthesis of $\mathrm{NH}_{3}-\mathrm{N}$ (lesser 


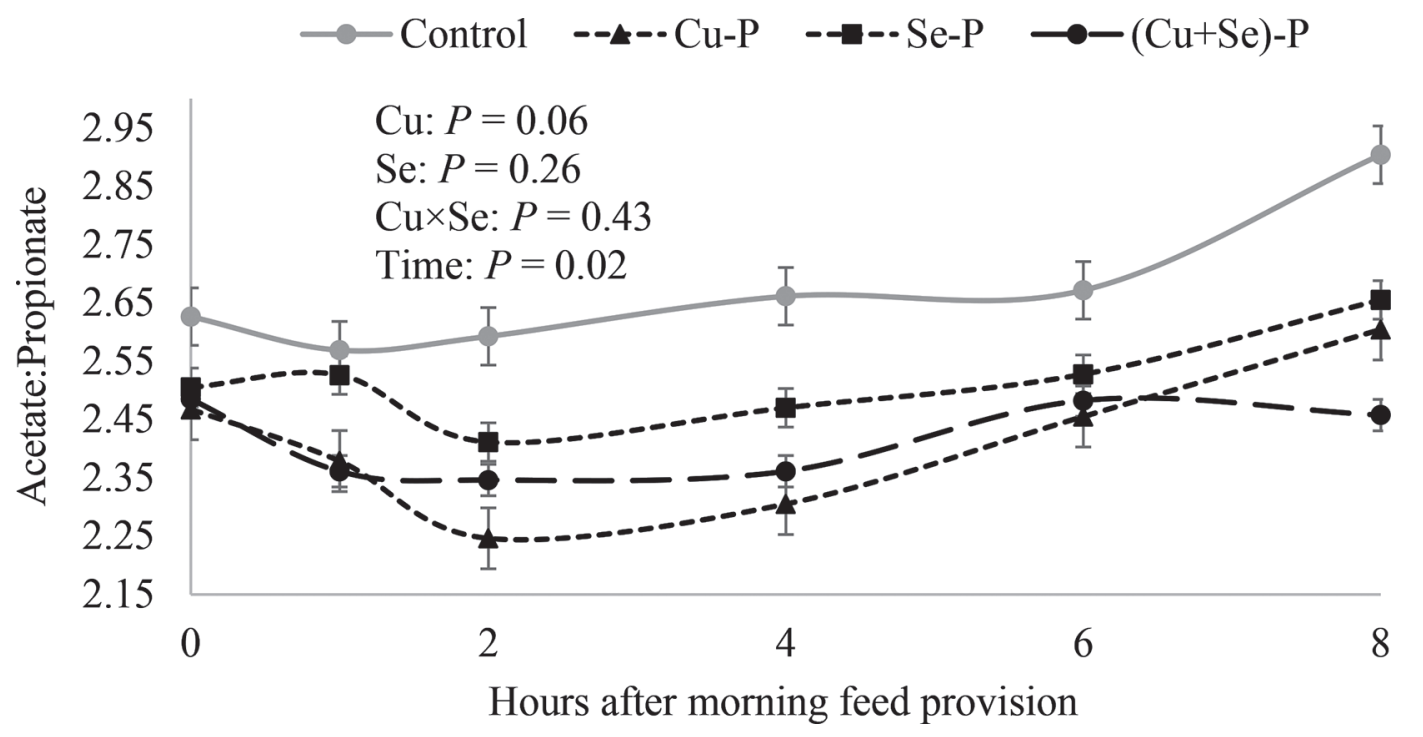

Figure 4. Effect of protection of $\mathrm{CuSO}_{4}$ and $\mathrm{Na}_{2} \mathrm{SeO}_{3}$ on diurnal variation of acetate:propionate ratio in a dual-flow continuous-culture system. Treatments: control (unprotected $\mathrm{CuSO}_{4}+$ unprotected $\mathrm{Na}_{2} \mathrm{SeO}_{3}$ ); Cu-P (protected $\mathrm{CuSO}_{4}+$ unprotected $\mathrm{Na}_{2} \mathrm{SeO}$ ); $\mathrm{Se}-\mathrm{P}$ (unprotected $\mathrm{CuSO}_{4}+$ protected $\left.\mathrm{Na}_{2} \mathrm{SeO}_{3}\right) ;\left(\mathrm{Cu}+\mathrm{Se}\right.$ )-P (protected $\mathrm{CuSO}_{4}+$ protected $\mathrm{Na}_{2} \mathrm{SeO}_{3}$ ). Effects: $\mathrm{Cu}$ (main effect of CuSO $\mathrm{C}_{4}$ protection); Se (main effect of $\mathrm{Na}_{2} \mathrm{SeO}_{3}$ protection); $\mathrm{Cu} \times \mathrm{Se}$ (interaction between $\mathrm{CuSO}_{4}$ protection and $\mathrm{Na}_{2} \mathrm{SeO}_{3}$ protection). Error bars represent the SEM.

ruminal protein degradation) or (2) increased uptake of $\mathrm{NH}_{3}-\mathrm{N}$ for microbial synthesis. As we did not observe any effects of $\mathrm{Na}_{2} \mathrm{SeO}_{3}$ protection on bacterial $\mathrm{N}$ flow, it is unlikely that improved microbial synthesis would have increased uptake of $\mathrm{NH}_{3}-\mathrm{N}$. Less ruminal degradation of protein may improve $\mathrm{N}$ utilization when diets with high concentration of protein are fed, such as the case of high producing dairy cows (NRC, 2001).

\section{Nutrient Digestibility}

Lipid-microencapsulation protection of $\mathrm{CuSO}_{4}$ did not have any effect on digestibility of DM, OM, CP, or NDF (Table 3). Similarly, Engle and Spears (2000) did not observe any effects of supplemental $\mathrm{CuSO}_{4}$ on $12 \mathrm{~h}$ in vitro dry matter digestibility when included at 0,10 , and $20 \mathrm{mg}$ of $\mathrm{Cu}$ per $\mathrm{kg}$ of substrate DM. Also, Arthington (2005) reported no effects of $\mathrm{CuSO}_{4}$ supplemented at 15,60 , and $120 \mathrm{mg} / \mathrm{kg}$ of $\mathrm{Cu}$ on apparent total-tract digestibility of DM in beef heifers fed a stargrass haybased diet plus a high energy supplement (ground corn and high S molasses). Copper sulfate was mixed with the high S molasses in this study (Arthington, 2005), which may have favored the formation of insoluble complexes of $\mathrm{Cu}$ and $\mathrm{S}$ in the rumen, minimizing the potential effect of $\mathrm{Cu}$ on digestibility.

Arthington (2005) reported a reduction in total-tract digestibility of NDF and CP in crossbred steers fed limpograss hay receiving an intraruminal bolus with 12.5 $\mathrm{g}$ of copper oxide. Average liver $\mathrm{Cu}$ concentration $>600$ $\mathrm{mg} / \mathrm{kg}$ in treated steers exceeded the normal range for cattle supplemented with $\mathrm{CuSO}_{4}$ under similar conditions (100-300 mg/kg), suggesting that the bolus might have provided a greater supply of $\mathrm{Cu}$ to the rumen than what is commonly supplemented through $\mathrm{CuSO}_{4}$, therefore increasing the chances of affecting nutrient digestibility.

More recently, hydroxy trace mineral sources with low solubility in water have been compared with traditional sulfate sources for ruminants. Genther and Hansen (2015) reported lower DM disappearance in cannulated steers fed sulfate sources than steers consuming hydroxy sources. For crossbred steers fed a high-grain finishing diet, Caldera et al. (2019) observed that NDF total-tract digestibility tended to be lower in sulfatesupplemented steers compared with animals consuming hydroxy minerals. Similarly, Guimaraes et al. (2019) reported lesser total-tract NDF digestibility for steers consuming low-quality hay plus a protein supplemented with sulfate sources, and Faulkner and Weiss (2017) found a decreased total-tract NDF digestibility in Holstein cows receiving sulfate trace minerals. These results show that sulfate minerals negatively affect nutrient digestibility; however, all of these trials evaluated the effects of source by simultaneously supplementing $\mathrm{Cu}, \mathrm{Zn}$, and $\mathrm{Mn}$ as either sulfate or hydroxy form, and therefore represent the additive effects of $\mathrm{Cu}, \mathrm{Zn}$, and $\mathrm{Mg}$ sulfates on nutrient digestibility, making it impossible to isolate the effect of $\mathrm{Cu}$.

Currently, most findings indicate that $\mathrm{Cu}, \mathrm{Mn}$, and Zn may affect ruminal digestion when fed together at recommended levels of supplementation (NRC, 2001; 
NASEM, 2016). Apparent negative effects of trace minerals on digestibility of NDF are attributed to greater concentration of $\mathrm{Cu}, \mathrm{Mn}$, and $\mathrm{Zn}$ in the ruminal fluid when these minerals are supplemented as sulfates (Genther and Hansen, 2015; Caldera et al., 2019). However, in most cases it is not possible to determine the individual effect of each mineral on ruminal digestibility.

In our experiment, lipid-coat protection of $\mathrm{CuSO}_{4}$ may have affected metabolism and interconversions of ruminal VFA without modifying nutrient digestion, causing a greater molar proportion of butyrate at expenses of acetate without affecting ruminal digestibility of nutrient fractions. This VFA-interconverting role has been previously described for Butyrivibrio (Hackmann and Firkins, 2015), which can transform ruminal acetate into butyrate. One could speculate that $\mathrm{Bu}$ tyrivibrio may have greater sensitivity to $\mathrm{CuSO}_{4}$ than other ruminal microorganisms, causing a shift in VFA molar proportions without major changes in substrate fermentation.

On the other hand, we found that protection of $\mathrm{Na}_{2} \mathrm{SeO}_{3}$ tended to decrease ruminal digestibility of $\mathrm{CP}$ $(P=0.06)$, but did not affect digestibility of DM, OM, or NDF (Table 3 ). These results are consistent with the trend toward reduced outflow of $\mathrm{NH}_{3}-\mathrm{N}$ and increased outflow of undigested dietary $\mathrm{N}$, indicating that protection of $\mathrm{Na}_{2} \mathrm{SeO}_{3}$ may have reduced $\mathrm{N}$ degradation in the rumen. However, as shown before, protection of $\mathrm{Na}_{2} \mathrm{SeO}_{3}$ only tended to reduce molar proportions of isovalerate and BCVFA (Figures 5 and 6, respectively), leaving it unclear if some of the dietary $\mathrm{N}$ that escaped microbial degradation with protected $\mathrm{Na}_{2} \mathrm{SeO}_{3}$ may correspond to other forms of $\mathrm{N}$ present in fraction $\mathrm{A}$ that are not AA.

Others have reported results that suggest possible relationships between ruminal metabolism of Se and N. Early observations by Rosenfeld and Beath (1964) in sheep consuming low (1.5\%), mid (12\%), or high (20\%) CP diets and supplemented with 10,15 , or 20 $\mathrm{mg}$ of Se daily, suggested that sheep consuming low and mid CP diets required less Se and took a shorter time to develop Se toxicosis (blood Se concentrations $>1.2$ $\mathrm{mg} / \mathrm{kg}$ ). This may have been due to impaired Se excretion capacity in protein deficient animals or related to $\mathrm{N}$ requirements by ruminal bacteria to synthesize Se-amino acids, primarily Se-methionine (Hidiroglou et al., 1968).

Selenium from inorganic sources such as $\mathrm{Na}_{2} \mathrm{SeO}_{3}$ and $\mathrm{Na}_{2} \mathrm{SeO}_{4}$ can be partially incorporated into Seamino acids of microbial protein; however, Se-amino acids present in organic sources of Se (such as Se yeast) are incorporated into microbial protein with greater efficiency (Galbraith et al., 2016). This may contribute to the greater bioavailability of organic Se sources due to the high digestibility of microbial protein (Weiss, 2005). Accordingly, intestinal absorption of organic Se as Se-methionine would be primarily determined by efficiency of digestion and absorption of microbial protein, while lipid-microencapsulated Se would be expected to prevent Se uptake by ruminal microbes, and

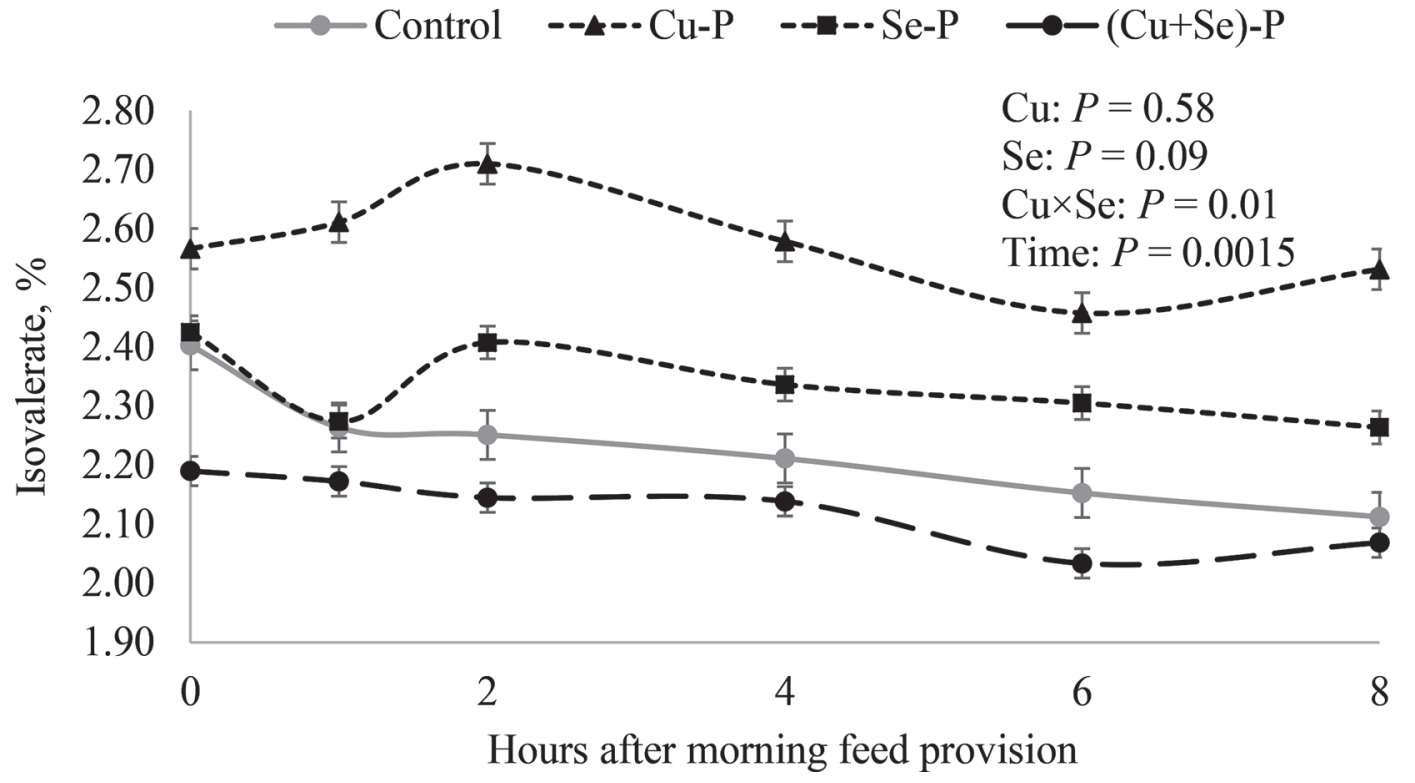

Figure 5. Effect of protection of $\mathrm{CuSO}_{4}$ and $\mathrm{Na}_{2} \mathrm{SeO}_{3}$ on diurnal variation of isovalerate molar proportion in a dual-flow continuous-culture system. Treatments: control (unprotected $\mathrm{CuSO}_{4}+$ unprotected $\mathrm{Na}_{2} \mathrm{SeO}_{3}$ ); $\mathrm{Cu}-\mathrm{P}$ (protected $\mathrm{CuSO}_{4}+$ unprotected $\mathrm{Na}_{2} \mathrm{SeO}$ ); Se-P (unprotected $\mathrm{CuSO}_{4}+$ protected $\left.\mathrm{Na}_{2} \mathrm{SeO}_{3}\right) ;(\mathrm{Cu}+\mathrm{Se})-\mathrm{P}$ (protected $\mathrm{CuSO}_{4}+$ protected $\mathrm{Na}_{2} \mathrm{SeO}_{3}$ ). Effects: $\mathrm{Cu}$ (main effect of CuSO $\mathrm{C}_{4}$ protection); $\mathrm{Se}$ (main effect of $\mathrm{Na}_{2} \mathrm{SeO}_{3}$ protection); $\mathrm{Cu} \times \mathrm{Se}$ (interaction between $\mathrm{CuSO}_{4}$ protection and $\mathrm{Na}_{2} \mathrm{SeO}_{3}$ protection). Error bars represent the SEM. 


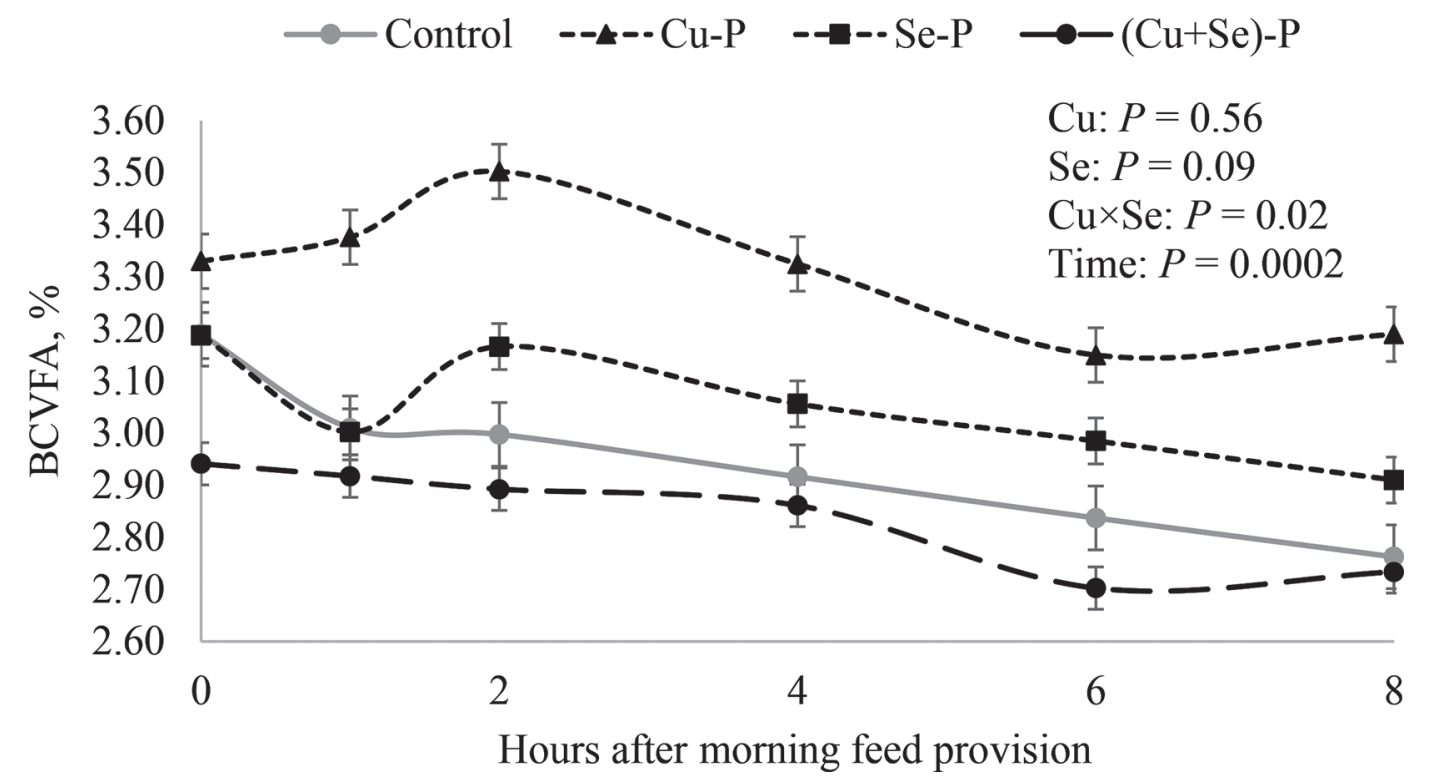

Figure 6. Effect of protection of $\mathrm{CuSO}_{4}$ and $\mathrm{Na}_{2} \mathrm{SeO}_{3}$ on diurnal variation of branched-chain VFA (BCVFA) molar proportion in a dual-flow continuous-culture system. Treatments: control (unprotected $\mathrm{CuSO}_{4}+$ unprotected $\mathrm{Na}_{2} \mathrm{SeO}_{3}$ ); $\mathrm{Cu}-\mathrm{P}$ (protected $\mathrm{CuSO}_{4}+$ unprotected Na $\mathrm{SeO}_{3}$ ); Se-P (unprotected $\mathrm{CuSO}_{4}+$ protected $\mathrm{Na}_{2} \mathrm{SeO}_{3}$ ); ( $\left.\mathrm{Cu}+\mathrm{Se}\right)-\mathrm{P}$ (protected $\mathrm{CuSO}_{4}+$ protected $\mathrm{Na}_{2} \mathrm{SeO}_{3}$ ). Effects: $\mathrm{Cu}$ (main effect of CuSO${ }_{4}$ protection); $\mathrm{Se}$ (main effect of $\mathrm{Na}_{2} \mathrm{SeO}_{3}$ protection); $\mathrm{Cu} \times \mathrm{Se}$ (interaction between $\mathrm{CuSO}_{4}$ protection and $\mathrm{Na}_{2} \mathrm{SeO}_{3}$ protection). Error bars represent the SEM.

consequently its efficiency of absorption in the intestine would primarily be a function of enzymatic digestion of the lipid protective matrix and subsequent absorption of Se as selenite. Therefore, bioavailability of lipid-microencapsulated Se needs to be evaluated to determine possible implications of protection on intestinal absorption and distribution of Se in different tissues.

Very few evaluations have been done to assess the effects of Se supplementation on nutrient digestibility in ruminants. Shi et al. (2011) observed a greater in

Table 2. Effect of protection of $\mathrm{CuSO}_{4}$ and $\mathrm{Na}_{2} \mathrm{SeO}_{3}$ on $\mathrm{pH}$ and $\mathrm{N}$ metabolism in a dual-flow continuous-culture system

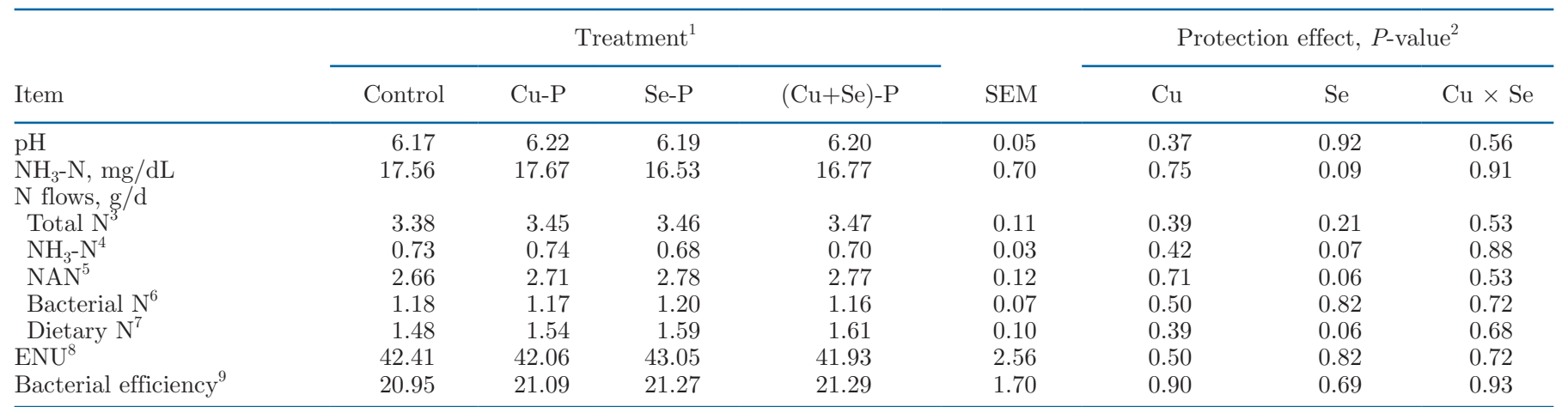

${ }^{1}$ Control (unprotected $\mathrm{CuSO}_{4}+$ unprotected $\mathrm{Na}_{2} \mathrm{SeO}_{3}$ ); Cu-P (protected $\mathrm{CuSO}_{4}+$ unprotected $\mathrm{Na}_{2} \mathrm{SeO}_{3}$ ); Se-P (unprotected CuSO $4+$ protected $\left.\mathrm{Na}_{2} \mathrm{SeO}_{3}\right) ;(\mathrm{Cu}+\mathrm{Se})-\mathrm{P}$ (protected $\mathrm{CuSO}_{4}+$ protected $\left.\mathrm{Na}_{2} \mathrm{SeO}_{3}\right)$.

${ }^{2} \mathrm{Cu}$ (main effect of $\mathrm{CuSO}_{4}$ protection); $\mathrm{Se}$ (main effect of $\mathrm{Na}_{2} \mathrm{SeO}_{3}$ protection); $\mathrm{Cu} \times$ Se (interaction between $\mathrm{CuSO}_{4}$ protection and $\mathrm{Na}_{2} \mathrm{SeO}_{3}$ protection).

${ }^{3}$ Total $\mathrm{N}=$ total $\mathrm{N}$ flow $(\mathrm{g} / \mathrm{d})=\mathrm{NH}_{3}-\mathrm{N}+\mathrm{NAN}$ (Bach and Stern, 1999).

${ }^{4} \mathrm{NH}_{3}-\mathrm{N}=$ ammonia $\mathrm{N}$ flow $(\mathrm{g} / \mathrm{d})=\mathrm{mg} / \mathrm{dL}$ of effluent $\mathrm{NH}_{3}-\mathrm{N} \times(\mathrm{g}$ of total effluent flow/100).

${ }^{5} \mathrm{NAN}=$ nonammonia $\mathrm{N}$ flow $(\mathrm{g} / \mathrm{d})=$ total $\mathrm{N}-\mathrm{NH}_{3}-\mathrm{N}$.

${ }^{6}$ Bacterial-N flow $(\mathrm{g} / \mathrm{d})=\left(\mathrm{NAN}\right.$ flow $\times \%$ atom excess of ${ }^{15} \mathrm{~N}$ in NAN effluent $) /\left(\%\right.$ atom excess of ${ }^{15} \mathrm{~N}$ in bacteria pellet $)$, according to Calsamiglia et al. (1996).

${ }^{7}$ Dietary $\mathrm{N}$ flow $(\mathrm{g} / \mathrm{d})=\mathrm{g}$ of effluent $\mathrm{NAN}-\mathrm{g}$ of effluent bacterial $\mathrm{N}$.

${ }^{8} \mathrm{ENU}=$ efficiency of $\mathrm{N}$ use $=(\mathrm{g}$ of bacterial $\mathrm{N} / \mathrm{g}$ of available $\mathrm{N}) \times 100($ Bach and Stern, 1999).

${ }^{9}$ Bacterial efficiency $=\mathrm{g}$ of bacterial $\mathrm{N}$ flow $/ \mathrm{kg}$ of OM truly digested (Calsamiglia et al., 1996). 
Table 3. Effect of protection of $\mathrm{CuSO}_{4}$ and $\mathrm{Na}_{2} \mathrm{SeO}_{3}$ on ruminal digestibility of DM, OM, CP, ADF, and NDF in a dual-flow continuous-culture system

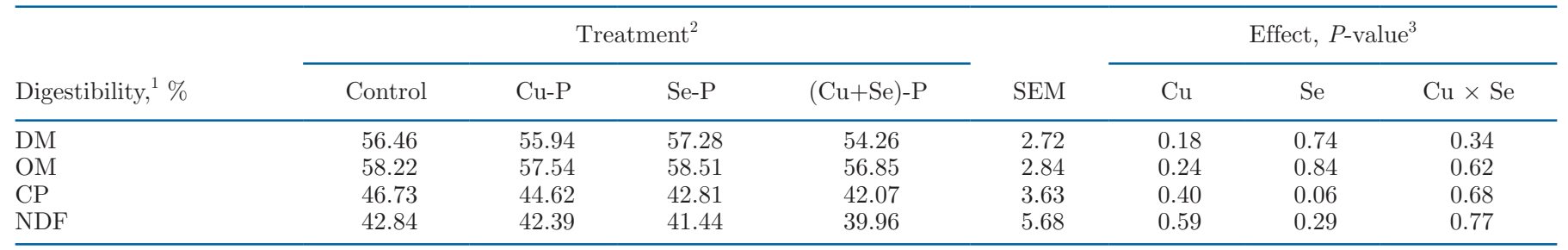

${ }^{1}$ True ruminal digestibility of DM, OM, and CP; apparent ruminal digestibility of NDF.

${ }^{2}$ Control (unprotected $\mathrm{CuSO}_{4}+$ unprotected $\mathrm{Na}_{2} \mathrm{SeO}_{3}$ ); Cu-P (protected $\mathrm{CuSO}_{4}+$ unprotected $\mathrm{Na}_{2} \mathrm{SeO}_{3}$ ); Se-P (unprotected CuSO${ }_{4}+$ protected $\left.\mathrm{Na}_{2} \mathrm{SeO}_{3}\right) ;(\mathrm{Cu}+\mathrm{Se})-\mathrm{P}$ (protected $\mathrm{CuSO}_{4}+$ protected $\left.\mathrm{Na}_{2} \mathrm{SeO}_{3}\right)$.

${ }^{3} \mathrm{Cu}$ (main effect of $\mathrm{CuSO}_{4}$ protection); Se (main effect of $\mathrm{Na}_{2} \mathrm{SeO}_{3}$ protection); $\mathrm{Cu} \times \mathrm{Se}$ (interaction between $\mathrm{CuSO}_{4}$ protection and $\mathrm{Na}_{2} \mathrm{SeO}_{3}$ protection).

situ ruminal degradability of $\mathrm{CP}$ from soybean meal and of forage DM and NDF in sheep fed nano Se at 0.3 , 3.0 , and $6.0 \mathrm{mg} / \mathrm{kg}$ compared with the unsupplemented control. Additionally, apparent total-tract digestibility of DM, CP, and NDF, as well as urinary excretion of purine derivatives, were greater for animals that received supplemental Se, supporting the idea of a possible effect of Se on ruminal degradation of nutrients including $\mathrm{N}$. Similarly, Alimohamady et al. (2013) found improved apparent total-tract digestibility of DM, CP, and NDF in sheep fed selenium-yeast $(0.2$ and $0.4 \mathrm{mg} / \mathrm{kg})$, but not in those fed inorganic Se $(0.2$ and $0.4 \mathrm{mg} / \mathrm{kg}$ from $\mathrm{Na}_{2} \mathrm{SeO}_{3}$ ) when compared with those fed a control diet (0.06 mg/kg Se). More recently, Wei et al. (2019) observed improved digestibility of DM, CP, and NDF in cows fed hydroxy-analog of Se-methionine compared with those fed a control diet, and greater $\mathrm{CP}$ and $\mathrm{NDF}$ digestibility compared with $\mathrm{Na}_{2} \mathrm{SeO}_{3}$. The changes observed in nutrient digestibility with organic sources of Se may be attributed to the effect of AA, which can be readily incorporated into microbial proteins (Galbraith et al., 2016).

The lack of effect of Se protection on ruminal digestibility of DM and NDF in our experiment may be related to the concentration of Se in the basal diet. Although not all of the studies report the basal concentration of Se, Alimohamady et al. (2013) and Wei et al. (2019) reported a concentration of $0.06 \mathrm{mg} / \mathrm{kg}$ of Se in their control unsupplemented diets, while the basal diet in our experiment had $0.12 \mathrm{mg} / \mathrm{kg}$. Therefore, the lack of effect of $\mathrm{Na}_{2} \mathrm{SeO}_{3}$ protection on DM and NDF digestibility in our study may be because feedstuffs in the basal diet were already providing a significant contribution to the total pool of available Se; consequently, the requirement of supplemental Se for an adequate fermentation was small. However, under the conditions of this experiment, protection of $\mathrm{Na}_{2} \mathrm{SeO}_{3}$ may have affected $\mathrm{NH}_{3}-\mathrm{N}$-producing bacteria to a greater extent than other types of microorganisms, favoring lower concentrations of $\mathrm{NH}_{3}-\mathrm{N}$ after feeding protected $\mathrm{Na}_{2} \mathrm{SeO}_{3}$.

\section{ACKNOWLEDGMENTS}

The authors acknowledge partial financial support from Jefo Nutrition Inc. (St. Hyacinthe, QC, Canada) for this research, and also thank Universidad de Costa Rica for providing a scholarship for Jose Arce-Cordero's PhD program. The authors have not stated any conflicts of interest.

\section{REFERENCES}

Alimohamady, R., H. Aliarabi, A. Bahari, and A. H. Dezfoulian. 2013. Influence of different amounts and sources of selenium supplementation on performance, some blood parameters, and nutrient digestibility in lambs. Biol. Trace Elem. Res. 154:45-54. https://doi .org/10.1007/s12011-013-9698-4.

AOAC. 1990. Official Methods of Analysis. 13th ed. Assoc. Off. Anal. Chem., Washington, DC.

AOAC International. 2000. Official Methods of Analysis. 17th ed. AOAC International, Washington, DC.

Arthington, J. D. 2005. Effects of copper oxide bolus administration or high-level copper supplementation on forage utilization and copper status in beef cattle. J. Anim. Sci. 83:2894-2900. https://doi.org/ $10.2527 / 2005.83122894 x$.

Bach, A., and M. D. Stern. 1999. Effects of different levels of methionine and ruminally undegradable protein on the amino acid profile of effluent from continuous culture fermenters. J. Anim. Sci. 77:3377-3384. https://doi.org/10.2527/1999.77123377x.

Brandao, V. L. N., and A. P. Faciola. 2019. Unveiling the relationships between diet composition and fermentation parameters response in dual-flow continuous culture system: A meta-analytical approach. Transl. Anim. Sci. 3:1064-1075. https://doi.org/10.1093/ tas/txz019.

Brandao, V. L. N., M. I. Marcondes, and A. P. Faciola. 2020. Comparison of microbial fermentation data from dual-flow continuous culture system and omasal sampling technique: A meta-analytical approach. J. Dairy Sci. 103:2347-2362. https://doi.org/10.3168/ jds.2019-17107.

Broderick, G. A., and J. H. Kang. 1980. Automated simultaneous determination of ammonia and total amino acids in ruminal fluid and in vitro media. J. Dairy Sci. 63:64-75. https://doi.org/10 .3168/jds.S0022-0302(80)82888-8. 
Caldera, E., B. Weigel, V. Kucharczyk, K. Sellins, S. L. Archibeque, J. J. Wagner, H. Han, J. W. Spears, and T. E. Engle. 2019. Trace mineral source influences ruminal distribution of copper and zinc and their binding strength to ruminal digesta. J. Anim. Sci. 97:1852-1864. https://doi.org/10.1093/jas/skz072.

Calsamiglia, S., M. D. Stern, and J. L. Firkins. 1996. Comparison of nitrogen-15 and purines as microbial markers in continuous culture. J. Anim. Sci. 74:1375-1381.

Engle, T. E., and J. W. Spears. 2000. Dietary copper effects on lipid metabolism, performance, and ruminal fermentation in finishing steers. J. Anim. Sci. 78:2452-2458. https://doi.org/10.2527/2000 $.7892452 x$.

Engle, T. E., J. W. Spears, V. Fellner, and J. Odle. 2000. Effects of soybean oil and dietary copper on ruminal and tissue lipid metabolism in finishing steers. J. Anim. Sci. 78:2713-2721. https:// doi.org/10.2527/2000.78102713x.

Eun, J. S., T. Z. Davis, J. M. Vera, D. N. Miller, K. E. Panter, and D. R. ZoBell. 2013. Addition of high concentration of inorganic selenium in orchardgrass (Dactylis glomerata L.) hay diet does not interfere with microbial fermentation in mixed ruminal microorganisms in continuous cultures. Prof. Anim. Sci. 29:39-45. https:/ /doi.org/10.15232/S1080-7446(15)30193-5.

Faulkner, M. J., and W. P. Weiss. 2017. Effect of source of trace minerals in either forage- or by-product-based diets fed to dairy cows: 1. Production and macronutrient digestibility. J. Dairy Sci. 100:5358-5367. https://doi.org/10.3168/jds.2016-12095.

Galbraith, M. L., W. R. Vorachek, C. T. Estill, P. D. Whanger, G. Bobe, T. Z. Davis, and J. A. Hall. 2016. Rumen microorganisms decrease bioavailability of inorganic selenium supplements. Biol. Trace Elem. Res. 171:338-343. https://doi.org/10.1007/s12011 $-015-0560-8$.

Genther, O. N., and S. L. Hansen. 2015. The effect of trace mineral source and concentration on ruminal digestion and mineral solubility. J. Dairy Sci. 98:566-573. https://doi.org/10.3168/jds.2014 -8624 .

Goff, J. P. 2018. Invited review: Mineral absorption mechanisms, mineral interactions that affect acid-base and antioxidant status, and diet considerations to improve mineral status. J. Dairy Sci. 101:2763-2813. https://doi.org/10.3168/jds.2017-13112.

Guimaraes, O., S. Jalali, J. J. Wagner, J. W. Spears, and T. E. Engle. 2019. The influence of trace mineral source on fiber digestion, rumen fermentation characteristics, and mineral solubility in beef cattle fed a low quality forage diet. J. Anim. Sci. 97(Suppl. 3):167. https://doi.org/10.1093/jas/skz258.344.

Hackmann, T. J., and J. L. Firkins. 2015. Maximizing efficiency of rumen microbial protein production. Front. Microbiol. 6:465. https:/ /doi.org/10.3389/fmicb.2015.00465.

Hall, M. B. 2015. Determination of dietary starch in animal feeds and pet food by an enzymatic-colorimetric method: Collaborative study. J. AOAC Int. 98:397-409.

Hidiroglou, M., D. P. Heaney, and K. J. Jenkins. 1968. Metabolism of inorganic selenium in rumen bacteria. Can. J. Physiol. Pharmacol. 46:229-232. https://doi.org/10.1139/y68-038.

Hidiroglou, M., and J. R. Lessard. 1976. The effect of selenium or vitamin $\mathrm{E}$ supplementation on volatile fatty acid content of rumen liquor in sheep fed a purified diet. Int. J. Vitam. Nutr. Res. 46:458-463.

Hoover, W. H., B. A. Crooker, and C. J. Sniffen. 1976. Effects of differential solid-liquid removal rates on protozoa numbers in continuous cultures of rumen contents. J. Anim. Sci. 43:528-534. https:// doi.org/10.2527/jas1976.432528x.

Hubbert, F. Jr., E. Cheng, and W. Burroughs. 1958. Mineral requirement of rumen microorganisms for cellulose digestion in vitro. J. Anim. Sci. 17:559-568. https://doi.org/10.2527/jas1958.173559x.

Kim, J., P. J. Van Soest, and G. F. Combs. 1997. Studies on the effects of selenium on rumen microbial fermentation in vitro. Biol. Trace Elem. Res. 56:203-213. https://doi.org/10.1007/BF02785393.

Kristensen, N. B., and D. Harmon. 2004. Splanchnic metabolism of volatile fatty acids absorbed from the washed reticulorumen of steers. J. Anim. Sci. 82:2033-2042. https://doi.org/10.2527/2004 .8272033x.

Krizsan, S. J., S. Ahvenjärvi, H. Volden, and G. A. Broderick. 2010. Estimation of rumen outflow in dairy cows fed grass silage-based diets by use of reticular sampling as an alternative to sampling from the omasal canal. J. Dairy Sci. 93:1138-1147. https://doi .org/10.3168/jds.2009-2661.

National Academies of Science, Engineering, and Medicine (NASEM). 2016. Nutrient Requirements of Beef Cattle. 8th ed. The National Academies Press, Washington, DC.

National Research Council (NRC). 2001. Nutrient Requirements of Dairy Cattle. 7th rev. ed. The National Academies Press, Washington, DC.

Pino, F., and A. J. Heinrichs. 2016. Effect of trace minerals and starch on digestibility and rumen fermentation in diets for dairy heifers. J. Dairy Sci. 99:2797-2810. https://doi.org/10.3168/jds.2015 -10034 .

Rosenfeld, I., and O. A. Beath. 1964. Selenium: Geobotany, Biochemistry, Toxicity, and Nutrition. Academic Press Inc., New York, NY.

Ruiz-Moreno, M., E. Binversie, S. W. Fessenden, and M. D. Stern. 2015. Mitigation of in vitro hydrogen sulfide production using bismuth subsalicylate with and without monensin in beef feedlot diets. J. Anim. Sci. 93:5346-5354. https://doi.org/10.2527/jas.2015 -9392 .

Serra, A. B., K. Nakamura, T. Matsui, T. Harumoto, and T. Fujihara. 1994. Inorganic selenium for sheep. II. Its influence on rumen bacterial yield, volatile fatty acid production, and total tract digestion of timothy hay. Asian-Australas. J. Anim. Sci. 7:91-96. https://doi .org/10.5713/ajas.1994.91.

Shamberger, R. J. 1983. Biochemistry of Selenium. Plenum Press, New York, NY.

Shi, L., W. Xun, W. Yue, C. Zhang, Y. Ren, Q. Liu, Q. Wang, and L. Shi. 2011. Effect of elemental nano-selenium on feed digestibility, rumen fermentation, and purine derivatives in sheep. Anim. Feed Sci. Technol. 163:136-142. https://doi.org/10.1016/j.anifeedsci .2010.10.016.

Soder, K. J., A. F. Brito, and M. D. Rubano. 2013. Effect of supplementing orchardgrass herbage with a total mixed ration or flaxseed on fermentation profile and bacterial protein synthesis in continuous culture. J. Dairy Sci. 96:3228-3237. https://doi.org/10 $.3168 / \mathrm{jds} .2012-6307$.

Spears, J. W. 2003. Trace mineral bioavailability in ruminants. J. Nutr. 133:1506S-1509S. https://doi.org/10.1093/jn/133.5.1506S.

Suttle, N. F. 1975. Changes in the availability of dietary copper to young lambs associated with age and weaning. J. Agric. Sci. 84:255-261. https://doi.org/10.1017/S0021859600052370.

Suttle, N. F. 1991. The interactions between copper, molybdenum, and sulphur in ruminant nutrition. Annu. Rev. Nutr. 11:121-140. https://doi.org/10.1146/annurev.nu.11.070191.001005.

Suttle, N. F. 2010. Mineral Nutrition of Livestock, 4th ed. CABI, Wallingford, UK.

Van Soest, P. J., J. B. Robertson, and B. A. Lewis. 1991. Methods for dietary fiber, neutral detergent fiber, and nonstarch polysaccharides in relation to animal nutrition. J. Dairy Sci. 74:3583-3597. https://doi.org/10.3168/jds.S0022-0302(91)78551-2.

Wei, J. Y., J. Wang, W. Liu, K. Z. Zhang, and P. Sun. 2019. Short communication: Effects of different selenium supplements on rumen fermentation and apparent nutrient and selenium digestibility of mid-lactation dairy cows. J. Dairy Sci. 102:3131-3135. https:// doi.org/10.3168/jds.2018-15455.

Weiss, W. 2005. Selenium sources for dairy cattle. Pages $61-71$ in Proc. Tri-State Dairy Nutrition Conference, Fort Wayne, IN. Dept. of Anim. Sci., The Ohio State Univ., Columbus.

Weller, R. A., and A. F. Pilgrim. 1974. Passage of protozoa and volatile fatty acids from the rumen of the sheep and from a continuous in vitro fermentation system. Br. J. Nutr. 32:341-351. https://doi .org/10.1079/BJN19740087. 